\title{
KÜLÖNBÖZŐ ENERGIAFORRÁSÚ LINEÁRIS TENGELYEK IRÁNYÍTÁSA
}

\section{CONTROLLING OF TWO DIFFERENT ENERGY DRIVEN LINEAR AXES}

\author{
Tóth Xénia Erzsébet ${ }^{1}$, Tóth János ${ }^{2}$ \\ ${ }^{I}$ Debreceni Egyetem, Müszaki Kar, Villamosmérnöki és Mechatronikai Tanszék, \\ 4028, Magyarország, Debrecen, Ótemetö utca, 2-4, tothxeniaerzs@gmail.com \\ ${ }^{2}$ Debreceni Egyetem, Müszaki Kar, Villamosmérnöki és Mechatronikai Tanszék, \\ 4028, Magyarország, Debrecen, Ótemetö utca, 2-4, Telefon: +36 (52) 415- \\ 155/77796,tothjanos@eng.unideb.hu
}

\begin{abstract}
In the industrial processes the linear movements and the positioning with high accuracy are really important. In this paper we controlled two different powered linear axes, one is electropneumatical, and the other one is electrical. This model has two main parts, the pneumatical one (a pneumatical transporter with magnetic clutch) is moving to the $\mathrm{x}$ direction, and the electrical one (servo engine with its linear axis) is positioning to the y direction. The communication network is created with the PLC (Programmable Logic Controller) via CANopen protocol and FHPP data profile.

Keywords: servo motor, linear axes, closed-loop control, PLC.

\section{Összefoglalás}

Az ipari folyamatokban a nagy pontosságú pozicionálási feladatok megvalósítása különösen fontos. Kettő különböző az iparban használt, de eltérő segédenergiával (elektropneumatikus, elektromos) müködő tengelyen transzlációs pozicionálást valósítottunk meg. A pneumatikus egység (mágneskuplungos pneumatikus transzporter) az x irányba végez pozicionálást, az elektromos egység (szervo motor és az általa meghajtott lineáris tengely) pedig az y irányba történő mozgást valósítja meg. A kommunikációs hálózatot egy programozható logikai vezérlővel (PLC) hoztuk létre CANopen protokollon és FHPP adat profilon keresztül.
\end{abstract}

Kulcsszavak: szervo motor, lineáris tengelyek, szabályozás, PLC.

\section{Bevezetés}

A cikk bázisát a pozicionálási feladat képezte. A Festo szervo motorral (x irány) hajtott lineáris egység kinematikai láncát egy arra merőleges transzlációs tengellyel is kibővítettük (y irány). A kiegészítő tengelyen való mozgást egy mágnes kuplungos pneumatikus transzporter valósítja meg. A munkaasztal lineáris mozgást végez a szervo motor által irányított elektromos meghajtású tengely alatt (1. ábra). Az egységek irányítását és összehangolását a PLC (Programmable Logic Controller) végzi. 


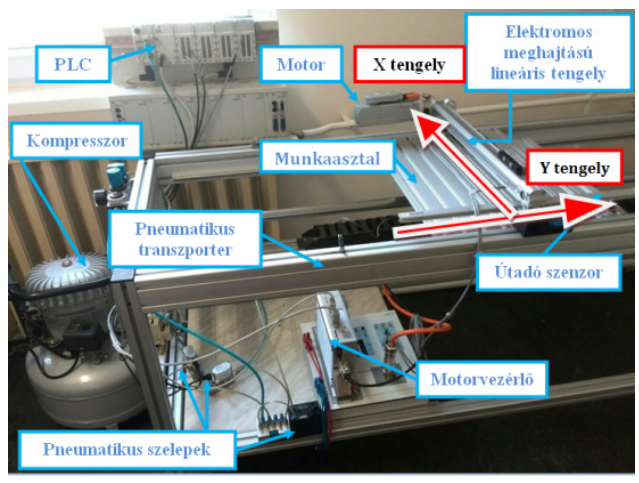

1. ábra. A megvalósitott modell

\section{Pneumatikus egység bemutatása}

Pneumatikus hajtások esetében előny, hogy a munkahenger sebessége fokozat nélkül állítható, viszont körülményes a pontos pozicionálás a levegő összenyomhatósága miatt.

\subsection{Pneumatikus rész felépítése}

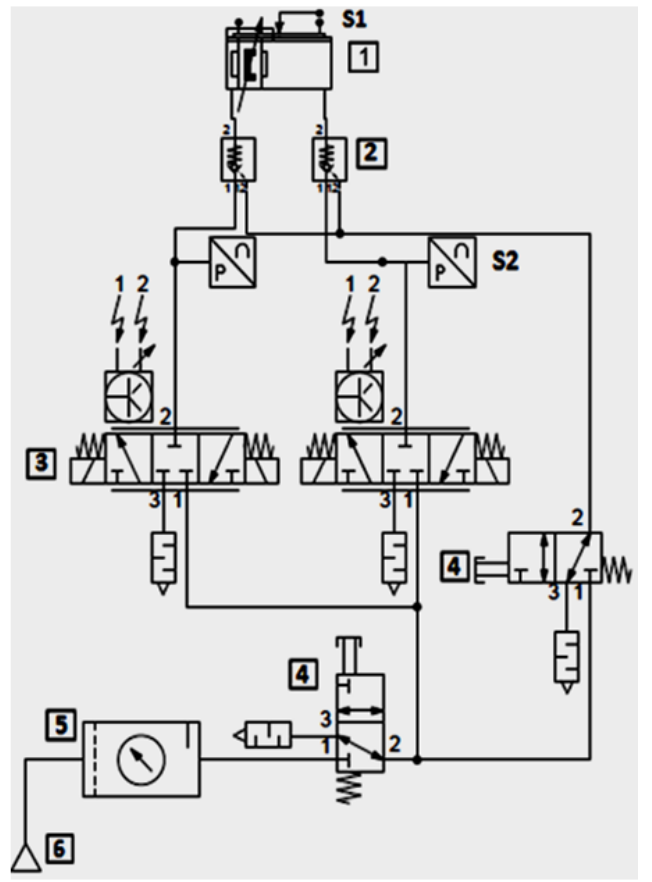

2. ábra. A pneumatikus egység kapcsolási rajza
A pneumatikus transzporter mozgásához kettő elektropneumatikus nyomásszabályozó szelepet, a pontos pozicionálásához egy 0-503 mm mérési tartományú útadószenzort használtunk fel.

A Rexroth D\&C Scheme Editor szoftver segítségével terveztük meg a pneumatikus egység kapcsolási rajzát (2. ábra). A pneumatikus kapcsolás a következő elemekből épül fel: egy kettős müködtetésü mágneskuplungos pneumatikus transzporter (1) útadó szenzorral felszerelve (S1), vezérelt visszacsapó szelepek (2), nyomásmérésre is használt (S2) 3/3-as monostabil elektropneumatikus nyomás-szabályozó szelep (3), monostabil, kézi müködtetésü 3/2-es pneumatikus útváltó szelep (4), levegő előkészítő egység (5), kompresszor (6).

\subsection{Szabályozás kialakítása}

A pneumatikus transzporter munkaasztalának pozícionálásához egy PID szabályozást használtunk, ami a PLC CODESYS programozó környezetében egy előre definiált funkcióblokként megtalálható. Ez könnyen paraméterezhetö, egyszerü behangolást tesz lehetővé, pontos pozícionálással.

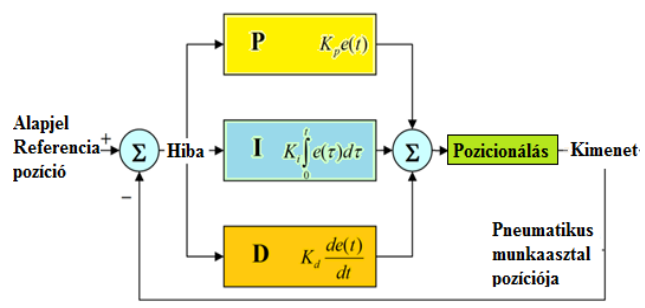

3. ábra. A PID szabályozás hatásvázlata

A szabályozás kimenetének megfelelően egymással ellentétesen vezéreljük a kettő elektropneumatikus nyomásszabályozó szelepet. A pneumatikus munkaasztal aktuális pozíciójáról a Hall-effektus elvén müködő útadó szenzor szolgáltat információt.

A szabályozás átviteli függvénye:

$$
u(t)=K_{P} e(t)+K_{I} \int_{0}^{t} e(t) d t+K_{D} \frac{d e}{d t}
$$


ahol $\mathrm{K}_{\mathrm{P}}$ az arányos átviteli tényező, $\mathrm{K}_{\mathrm{I}} \mathrm{az}$ integráló átviteli tényező $[1 / \mathrm{s}], \mathrm{K}_{\mathrm{D}}$ a differenciáló átviteli tényező [s] és e(t) az aktuális hiba.

A szabályozás lényege, hogy a szabályozott jellemző mért y értékét (pneumatikus munkaasztal pozíciója) összehasonlítja az y0 alapjellel. A különbségükből (a hibajelből, e - error) ezután megadható az új beavatkozó jel (u) értéke, hogy a y közelebb kerüljön y0 alapjelhez [1]. A PID szabályozás három tag, egy arányos $(\mathrm{P})$, egy integráló (I) és egy deriváló (D) párhuzamos kapcsolásával valósult meg.

A szabályozás beállítását a ZieglerNichols módszerrel végeztük el [2]. Ennek eredményeképp a szabályozás stabil, lengésektöl mentes lett.

\section{Az elektromos meghajtású egy- ség bemutatása}

Az y irányban megvalósuló mozgást egy Festo gyártmányú szervo motor teszi lehetővé, amellyel 0-300 mm nagyságú tartományban történik a pozicionálás egy fogas szíjas meghajtású lineáris tengelyen.

\subsection{Központi szabályozó egység}

A szabályozást végző központi egység egy moduláris felépítésü programozható logikai vezérlő (PLC), amelynek a Festo CPX-CEC-M1 típust választottuk. Feladata a motor, illetve a pneumatikus arányos szelepek vezérlése, a szabályozás megvalósítása, a szenzor adatok begyüjtése, illetve a számítógéppel való kommunikáció.

A CPX-CM-HPP kommunikációs modullal kiegészítve a PLC CAN buszon keresztül valósítja meg a motor vezérlését. A kommunikáció az erre a célra fejlesztett FHPP (Festo Handling and Positioning Profile) adatprofilon keresztül jön létre. Az elektromos meghajtású lineáris egységet vezérlő program alap szerkezetét a Case függvény használatával valósítottuk meg. A programkódot strukturált szöveges prog- ramnyelvvel készítettük el, a PLC CODESYS fejlesztőkörnyezetében.

\subsection{A kommunikáció megvalósítása}

Az FHPP adat profilt használva a motorvezérlő 4 tengely konfigurálásához és irányításához (CAN buszon keresztül) 32 byte adatterület áll rendelkezésre. Ebből egy tengelyt használva 8 byte-ot veszünk igénybe a motorok irányításához.

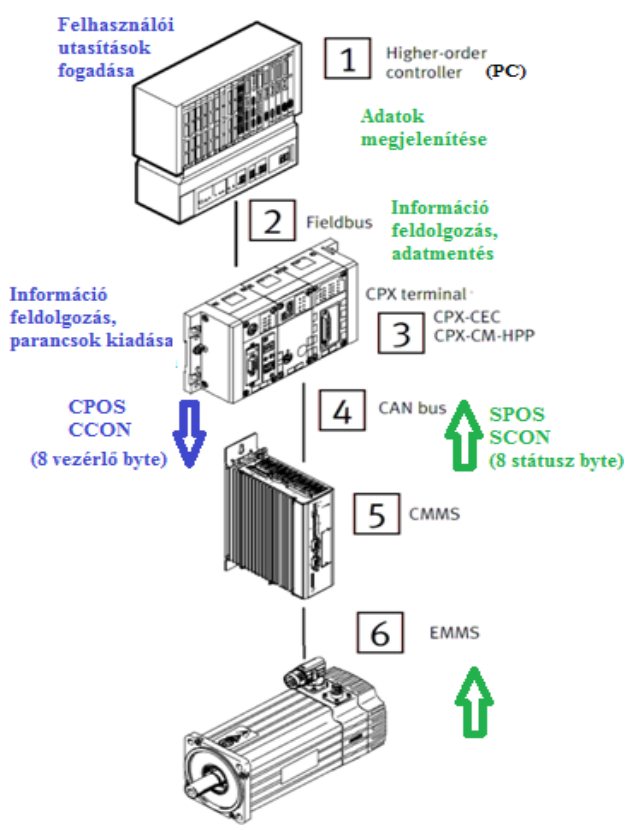

\section{4. ábra: Az eszközök közötti kommunikáció}

Kettő különböző mód választható, az úgynevezett Record select beállítással a motorvezérlőben konfigurált diszkrét pozíciók és dinamikai tulajdonságok érhetőek el. A Direct mode kiválasztásával (a másikkal ellentétben) a PLC által küldött tetszöleges pozíció, illetve sebesség is beállítható, és dinamikusan változtatható. Az eszközök közötti adatcsere a vezérlő és státusz byteok használatával valósul meg (4. ábra). 


\section{Megjelenítő felület bemutatása}

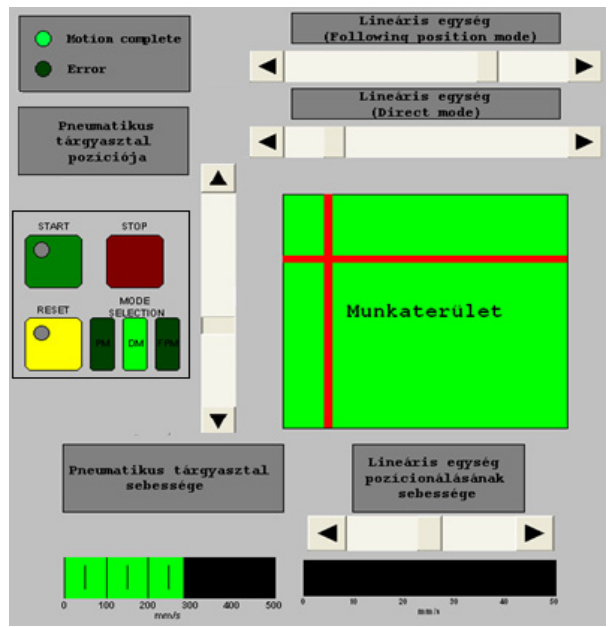

5. ábra: Az elkészitett felhasználói felület

Az általunk készített kezelöfelületen (5. ábra) elérhetővé tettük a pneumatikus tárgyasztal és az elektromos meghajtású tengely szánjának (az ábrán: lineáris egység) pozicionálását, amelyeket csúszkákkal valósítottunk meg. Az általuk behatárolt munkaterületet is megjelenítve, a csúszkák állapotához hozzárendelt függőleges és vízszintes piros szakaszok metszéspontja jelöli a pneumatikus szán és az elektromos szán függőleges vetületét a munkaasztalra. Az operátor a kezelöpanellel irányíthatja a rendszert, valamint elhelyezésre került a Start, Stop, Reset gomb és a Mód választó kapcsolók. Az aktuális állapotokról a státusz LED-ek adnak visszajelzést.

A bal oldali függőleges csúszka felel a pneumatikus tárgyasztal pozíciójának megadásáért. A lineáris egység pozicionálásához kettő mód közül is lehet választani a vezérlőpanelen található kapcsolókra kattintva. Az alsó skálák üzemmódtól függetlenül kijelzik a szánok aktuális sebességét.

A munkaterület fölött található Direct módhoz tartozó csúszkával beállítható a szán adott pozícióra, illetve a munkaterület jobb oldalán lévő skála segítségével hozzárendelhető a mozgáshoz sebesség érték is.

Másik lehetőség az általunk kialakított Following Position Mode, ezzel arányosan a lineáris egység szánja valós időben folyamatosan képes lekövetni a csúszka mozgását és annak változási sebességét is.

\section{5. Összegzés}

A kettő különböző energiaforrású tengellyel megvalósítottuk a pozicionálást Festo lineáris hajtástechnikával, valamint megterveztük és összeállítottuk a pneumatikus kapcsolást. Létrehoztuk a CANopen kommunikációs hálózatot FHPP adat profilon keresztül. Egy PID szabályozást használtuk fel a pneumatikus transzporter munkaasztalának pozicionálására. Bemutattuk a kezelő személy és a szervo rendszer közötti kommunikációhoz és a teszteléshez elkészített felhasználói felületet. A jelen konstrukció bővíthető különböző fejegységekkel, amivel rajzolási (toll), vagy áthelyezési (megfogó) műveleteket tudunk végrehajtani.

\section{Szakirodalmi hivatkozások}

[1] http://www.eet.bme.hu/ nagyg/elektronika/A \%20digitalis\%20PID\%20szabalyozo.pdf Letöltve:2014.11.03.

[2] U. Tietze, Ch. Schenk: Analóg és digitális áramkörök, Müszaki Könyvkiadó, Budapest, 2000. ISBN: 9631600106.

[3] David Hoey, Dan Sandoval, Edward Gasper: TP 800 e-drives - Reference notes, Festo Didactic GmbH \& Co., D-73770 Denkendorf, 2002

[4] Pozicionálás pneumatikával és szervo motorral - saját video:

https://www.youtube.com/watch? v=nTxxvHRT10\&feature $=$ youtube

[5] Tóth Xénia Erzsébet: Tetszöleges transzlációs pozicionálás megvalósitása ipari vezérlövel, Debreceni Egyetem, Müszaki Kar, Tudományos Diákköri Konferencia, Debrecen, 2014. 